
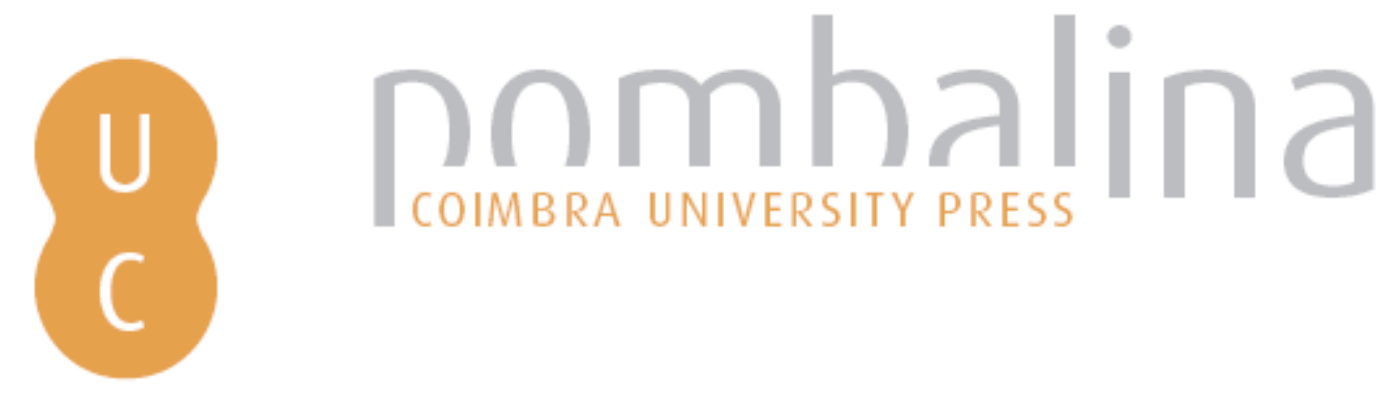

\title{
Literature review on the transition from smouldering to flaming fires and its application to peat fires
}
Autor(es):
Santoso, Muhammad Agung; Yang, Jiuling; Chen, Haixiang; Rein, Guillermo

Publicado por: Imprensa da Universidade de Coimbra

URL persistente:

URI:http://hdl.handle.net/10316.2/44575

DOI:

DOI:https://doi.org/10.14195/978-989-26-16-506_58

Accessed : $\quad$ 26-Apr-2023 15:50:39

A navegação consulta e descarregamento dos títulos inseridos nas Bibliotecas Digitais UC Digitalis, UC Pombalina e UC Impactum, pressupõem a aceitação plena e sem reservas dos Termos e Condições de Uso destas Bibliotecas Digitais, disponíveis em https://digitalis.uc.pt/pt-pt/termos.

Conforme exposto nos referidos Termos e Condições de Uso, o descarregamento de títulos de acesso restrito requer uma licença válida de autorização devendo o utilizador aceder ao(s) documento(s) a partir de um endereço de IP da instituição detentora da supramencionada licença.

Ao utilizador é apenas permitido o descarregamento para uso pessoal, pelo que o emprego do(s) título(s) descarregado(s) para outro fim, designadamente comercial, carece de autorização do respetivo autor ou editor da obra.

Na medida em que todas as obras da UC Digitalis se encontram protegidas pelo Código do Direito de Autor e Direitos Conexos e demais legislação aplicável, toda a cópia, parcial ou total, deste documento, nos casos em que é legalmente admitida, deverá conter ou fazer-se acompanhar por este aviso.

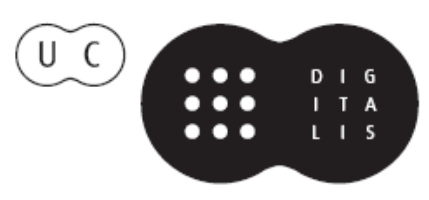




\section{ADVANCES IN}

\section{FOREST FIRE RESEARCH}

\section{8}

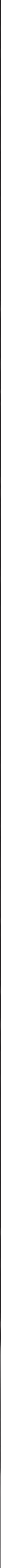




\title{
Literature review on the transition from smouldering to flaming fires and its application to peat fires
}

\author{
Muhammad Agung Santoso ${ }^{1}$, Jiuling Yang ${ }^{2}$, Haixiang Chen ${ }^{2}$ and Guillermo Rein*1 \\ ${ }^{1}$ Department of Mechanical Engineering, Imperial College London, UK \{g.rein@imperial.ac.uk*\} \\ ${ }^{2}$ State Key Laboratory of Fire Science, University of Science and Technology of China, P.R. China
}

\begin{abstract}
Smoldering combustion is the slow, low temperature, flameless burning of porous fuels and the most persistent type of combustion phenomena. Overall, smoldering is responsible for up to $50 \%$ or more of the total burned biomass during wildfires, and it is the driving phenomenon of wildfires in peatlands. Once ignited, peat fires burn for very long periods of time (e.g., months, years) despite extensive rains, weather changes or fire-fighting attempts. In wildland fires, smouldering and flaming combustion often occur simultaneously, and one can lead to the other. Despite being a fundamental question in combustion phenomenon, firm understanding on transition from smouldering to flaming is not yet accomplished due to its complexity. At best, literatures are sparsely connected with each literature reported different variables as transition criteria (e.g. sample particle size, air velocity, oxygen concentration, and external heating). This review compiles these informations and proposes hyprothesis that feasible to be tested. Since most of the samples in the literatures represent synthetic porous fuels, the implication of proposed hypothesis of transition mechanism on natural porous fuels (e.g. peat) will be discussed.
\end{abstract}

Keywords: Smouldering, Transition to flaming, porous fuels, peatlands,

\section{Introduction}

Smouldering combustion is the slow, low temperature, flameless burning of porous fuels and the most persistent type of combustion phenomena. Overall, smouldering is responsible for up to $50 \%$ or more of the total burned biomass during wildfires, and it is the driving phenomenon of wildfires in peatlands. Once ignited, peat fires burn for very long periods of time (e.g., months, years) despite extensive rains, weather changes or fire-fighting attempts. Typical in wildland fires, smouldering and flaming combustion often occur simultaneously, and one can lead to the other. Despite being a fundamental question in the science of combustion, firm understanding is not yet accomplished due to its complexity. At best, literature on transition from smouldering to flaming are sparsely connected with each literature reported different variables as transition criteria (e.g. sample particle size, air velocity, oxygen concentration, and external heating). This review compiles these information and proposes hyprothesis that feasible to be tested. Since most of the samples in the literature represent synthetic porous fuels, the implication of proposed hypothesis of transition mechanism on natural porous fuels (e.g. peat) will be discussed.

Figure 1 shows schematic on the possible concurrent events of smouldering peat and flaming surface vegetation. The complex interaction between these two combustion mechanisms and surrounding conditions could lead to the transition from smouldering to flaming combustion, and vice versa. 


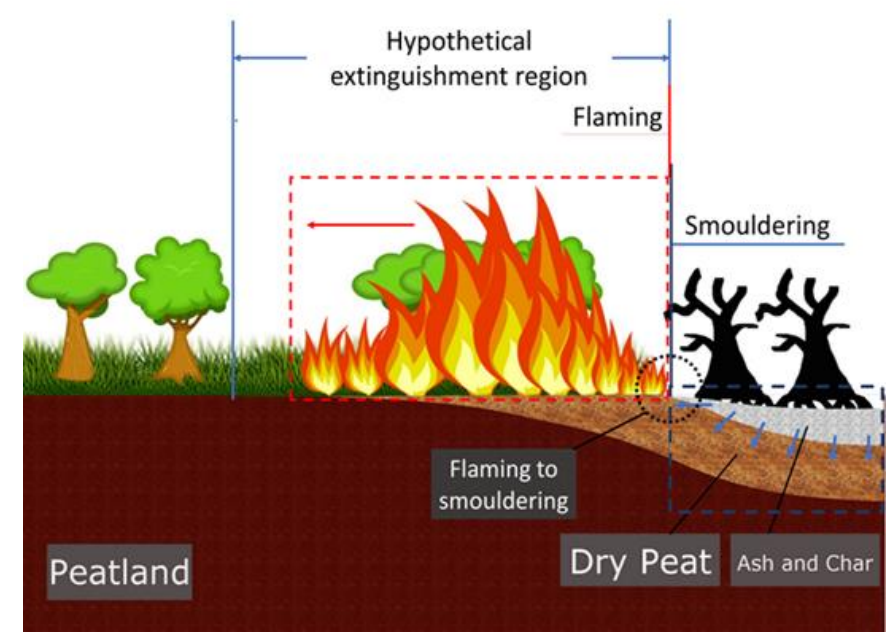

Figure 1 - Schematic on occurrence of smouldering initiation by flaming surface fires in peatland

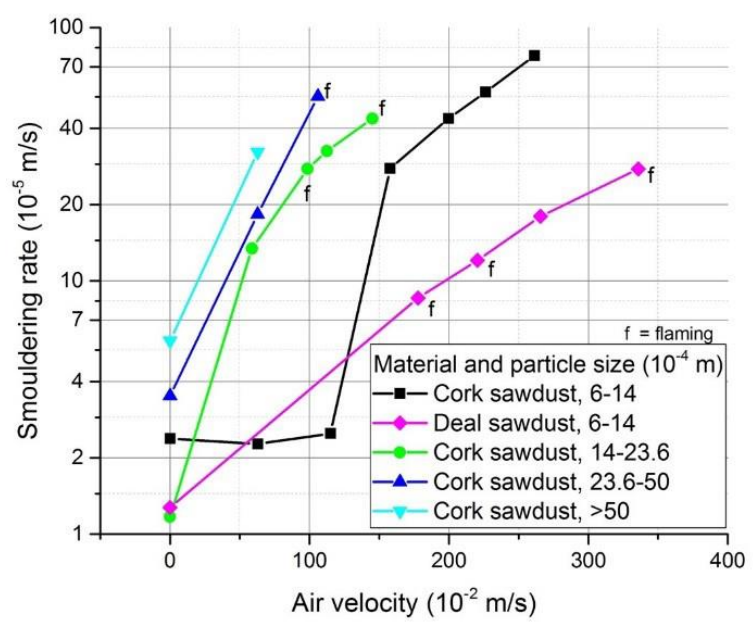

Figure 2 - Smouldering rate as a function of air velocity in a forward smouldering in Cork and Deal sawdust with different particle size (Palmer 1957)

The persistent smouldering of thick fuels (ie, tree branches, trunks) typically observed for days after a flaming wildfire has passed by is called residual smouldering combustion and has received some attention in the literature, e.g. Bertschi et al. (2003). On the other hand, transition to flaming offers the means for flaming fronts to re-establish in unexpected locations (e.g., across a fire break) and at unexpected times (e.g., long after burn out of the initial flaming front). Even if the transition to flaming is less often observed in wildfires than residual smouldering combustion because it requires less usual thermodynamic conditions, the transition to flaming is possible for example under enhanced oxygen supply (i.e., strong winds)

\subsection{Smouldering and Flaming Combustion}

The core of any combustion process is a global exothermic reaction that results in the release of heat, and both gaseous and solid products. In its simplest form, solid combustion can be approximated by two lumped chemical pathways: pyrolysis (Eq. 1) followed by oxidation (Eq. 2 or 3).

Pyrolysis:

Biomass (solid) + Heat $\rightarrow$ Pyrolyzate (gas) + Char (solid) + Ash (solid)

Heterogeneous oxidation:

Char (solid) $+\mathrm{O}_{2} \rightarrow$ Heat $+\mathrm{CO}_{2}+\mathrm{H}_{2} \mathrm{O}+$ other gases + Ash (solid)

Gas-phase oxidation:

Pyrolyzate (gas) $+\mathrm{O}_{2} \rightarrow$ Heat $+\mathrm{CO}_{2}+\mathrm{H}_{2} \mathrm{O}+$ other gases

Pyrolysis results in gaseous and solid products. Both the pyrolysate and the char are susceptible to subsequent oxidation. Char oxidation (Eq. 2) is a heterogeneous reaction and takes place on the char produced by the pyrolysis reaction and leads to smouldering combustion. Pyrolysate oxidation (Eq. 3) is airborne and takes place in the gas phase, which is a homogenous reaction and leads to flaming combustion. 


\section{Early Findings of transition to flaming}

One of the first recorded results on transition to flaming was conducted by Palmer (1957) with several types of dust as sample material. In his experiments, flaming did not develop from smouldering experiments with mean particle diameter less than $0.1 \mathrm{~cm}$ (Figure 2).

The influences of ambient oxygen concentration on transition phenomenon was studied by OrtizMolina et al. (1979). A synthetic porous fuel were placed in a chamber in which gas composition and pressure can be varied. Transition to flaming occurred at oxygen concentration ranged from 0.17 to 0.37 mole fraction for samples of relatively large size $(50 \times 120 \times 450 \mathrm{~mm})$. The samples in the form of small cylinders (18 $\mathrm{mm}$ in diameter) did not experienced transition. In another study by Roger and Ohlemiller (1980), the importance of oxygen supply on transition to flaming was confirmed. They investigated the opposed smouldering of flexible synthetic porous fuel in variable oxygen concentration. From their experiment, the transition occurred in oxygen mole fraction more than 0.6. The higher oxygen concentration was related to the weak response of opposed smouldering to air flow velocity. Ohlemiller (1990) investigated the influence of air flow velocity in forward and opposed smouldering of cellulosic insulation. He found that the opposed smouldering has weak response to air velocity increase, while forward smouldering increases significantly with flow velocity. Moreover, the transition to flaming was identified to only occur in forward smouldering, in range of air flow velocity up to $5 \mathrm{~m} / \mathrm{s}$.
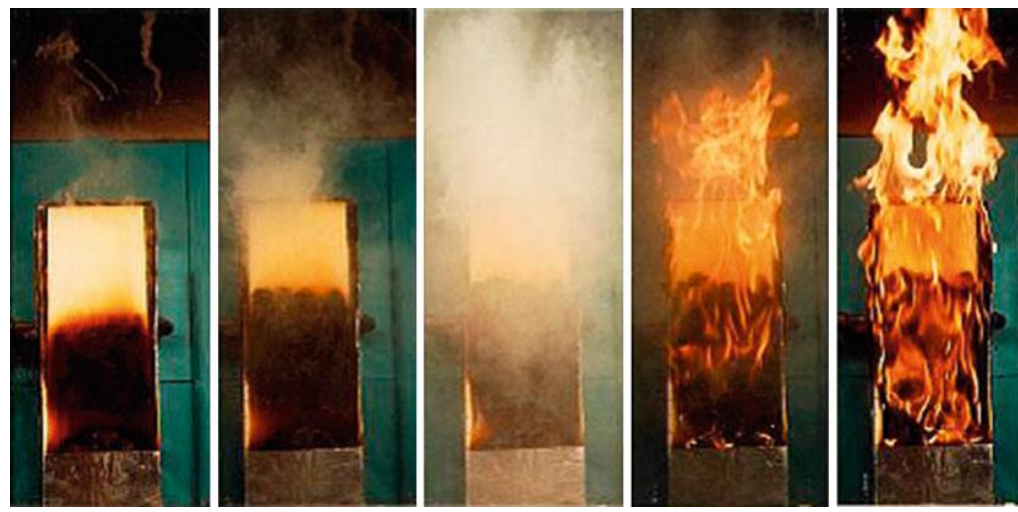

Figure 3 - Series of photographs of a combustion experiment illustrating the transition to flaming in a smouldering foam slab 40 cm high under external forced flow (Photo by group of Prof. Carlos Fernandez-Pello, University of California at Berkeley). After 1 h of smouldering only half the sample has burned (Photo 1, far left). When the rapid transition to flaming takes place (Photos 2 and 3), the whole sample is engulfed in flames in just a few seconds (Photos 4 and 5, far right)

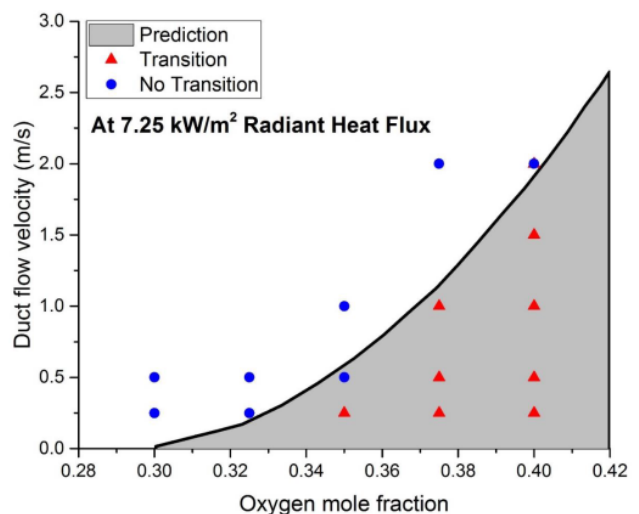

Figure 4 - Comparison of experimental results with the energy balance analysis prediction of transition/no transition regions as a function of oxygen mole fraction (Bar-Ilan et al. 2005)

\section{Current understanding of transition to flaming}

The most recent findings on the mechanism of transition from smouldering to flaming were mainly derived from the collective works of the Combustion and Fire Processes Lab of the University of California at Berkeley, USA. The works were carried out on syntethic porous media (i.e. PU foam) with variable oxidizer supply and radiant heat flux. Figure 3 shows snapshots of an experiment on the transition to flaming in a foam slab.

Bar-Ilan et al. (2005) carried out a simplified energy balance analysis by viewing the transition to flaming as an autoignition process. This analysis well predict the boundary between transition and notransition occurrences from experiments (Figure 4). Later, experiments by Bar-Ilan et al. (2005) and Putzeys et al. (2007) were reproduced computationally by Dodd et al. (2012) using two dimensional numerical transport model with eight-step reaction mechanism. Thermal non-equilibrium approach 
was taken to consider distinct temperature of solid and gas species. Even if there are some difference between experimental and simulation results, they relatively comparable and provide the basis for the development of predictive model of transition to flaming.

Char oxidation has been considered to lead to transition to flaming. This is from the argument that char oxidation produced the required heat to initiate combustion of gaseous fuel produced by solid reactions. Aldushin et al. (2006) numerically investigate the role of char oxidation in triggering transition to flaming. When smouldering front has been steadily propagate to a critical distance, char oxidation caused the sudden increase of temperature at reaction front. This increase is argued to be the initiation of flaming. In other study, char oxidation also considered to be an essential triggering mechanism of transition to flaming (Torero and Fernandez-Pello 1995, Tse et al. 1996, Putzeys et al. 2007, Dodd et al. 2012). In some literature, char oxidation also considered to produce the required gaseous fuel (Tse et al. 1996, Putzeys et al. 2007, Hagen et al. 2015). Investigation on which reaction that produce the gaseous fuel is where kinetics come into play. This is where further test on previous proposed mechanism is needed to fill the gap. It is whether pyrolysis or char oxidation is the primary source of gaseous fuel. By considering the different endothermicity and oxygen dependency of those reactions, this investigation could contribute to a better understanding of kinetics that lead to transition to flaming.

Experimental study on transition to flaming on cotton was conducted by Hagen et al. (2015). The boundary conditions used were open boundary and a lightweight concrete block covering one side of the sample. The occurrence of transition resulted from the difference in the smouldering velocity in the cotton. This difference exist due to the cover of the lightweight concrete. Thus, the existence of cover is important in the occurrence of transition in this study, implying the asymmetrical boundary condition.

Recent computational study on transition to flaming was carried out by Yang et al. (in press). They computationally reproduced forward horizontal smouldering of cellulosic insulation experiments of Ohlemiller (1990). The proposed computational model is two dimensional multiphase formulations with three-step solid decomposition reaction and one-global gas phase reaction. Three condensed phase species (solid sample, char, and ash) and five gas species (pseudo fuel gas species, $\mathrm{O}_{2}, \mathrm{~N}_{2}, \mathrm{CO}_{2}$, and $\mathrm{H}_{2} \mathrm{O}$ ) were used in the model. The model shows the transition to flaming occurence that located on the sample surface, in which the hotter surface char layer acts as an ignition source while the combustible gas fuel produced by surface char oxidation and solid sample pyrolysis. This work agrees well with Ohlemiller (1990) in that it well predicts smouldering velocity responses to wind velocity and bulk density.

\section{References}

Aldushin, A. P., Bayliss, A., Matkowsky, B. J., "On the transition from smoldering to flaming," Combustion and Flame 145, p. 579-606, 2006.

Bar-Ilan, A., Putzeys, O. M., Rein, G., Fernandez-Pello, C., Urban, D. L., "Transition from forward smoldering to flamingin small polyurethane foam samples," in Proceedings of the Combustion Institute, 2005.

Bertschi, I., Yokelson, R. J., Ward, D. E., Babbitt, R. E., Susott, R. A., Goode, J. G., Hao, W. M., "Trace gas and particle emissions from fires in large diameter and belowground biomass fuels," Journal of Geophysical Research, Vol. 108, No. D13, 8472, doi:10.1029/2002JD002100, 2003.

Dodd, A. B., Lautenberger, C. , Fernandez-Pello, A. C., "Computational modeling of smolder combustion and spontaneous transition to flaming," Combustion and Flame, vol. 159, p. 448, 2012. 
Hagen, B. C., Frette, V., Kleppe, G., Arntzen, B. J., "Transition from smoldering to flaming fire in short cotton samples with asymmetrical boundary conditions," Fire Safety Journal, vol. 71, p. 69, 2015.

Ohlemiller, T. J., "Forced Smolder Propagation and the Transition to Flaming in Cellulosic Insulation," Combustion and Flame, vol. 81, p. 354, 1990.

Ortiz-Molina, M. G., Toong, T.-Y., Moussa, N. A., Tesoro, G. C., "Smoldering Combustion of Flexible Polyurethane Foams and Its Transition to Faming or Extinguishment," Colloquium on Fire and Explosion, 1979

Palmer, K. N., "Smouldering Combustion in Dusts and Fibrous Materials," Combustion and Flame, vol. 1, no. 2, p. 129, 1957.

Putzeys, O., Bar-Ilan, A., Rein, G., Fernandez-Pello, A. C., Urban, D. L., "The role of secondary char oxidation in thetransition from smoldering to flaming," in Proceedings of the Combustion Institute, 2007.

Rogers, F. E. and Ohlemiller, T. J., "Smolder Characteristics of Flexible Polyurethane Foams,” Journal of Fire and Flammability, vol. 11, pp. 32-44, 1980.

Torero, J. L., Fernandez-Pello, A. C., "Natural Convection Smolder of Polyurethane Foam, Upward Propagation," Fire Safety Journal 24, pp. 35-52, 1995.

Tse, S. D., Fernandez-Pello, A. C., Miyasaka, K., "Controlling Mechanisms in the Transition from Smoldering to Flaming of Flexible Polyurethane Foam," Twenty-Sixth Symposium (International) on Combustion/The Combustion Institute, pp. 1505-1513, 1996.

Yang, J., Liu, N., Chen, H., "Smoldering and Spontaneous Transition to Flaming over Cellulosic Insulation," Proceedings of The Combustion Institute, in press. 